\title{
PENGARUH METODE BERMAIN PERAN DENGAN MEDIA BONEKA TANGAN TERHADAP KEMAMPUAN BERBICARA PADA SISWA TK (4-5 tahun) Budhiyasa Sangsit
}

\author{
(The Effect of Role Playing Methods of Media Hand Puppets on the Speaking Ability of \\ Students TK (4-5 years) Budhiyasa Sangsit)
}

\author{
Kadek Devy Marleni ${ }^{1}$, Putu Windi Ridayanti ${ }^{2}$, Ni Nyoman Laras \\ Sintya Dewi ${ }^{3}$
}

Program Studi S1 Keperawatan, Sekolah Tinggi Ilmu Kesehatan Buleleng Email devy26marleni@gmail.com

\begin{abstract}
ABSTRAK
Pendahuluan: Media boneka tangan merupakan boneka yang dijadikan media atau alat bantu yang digunakan dalam kegiatan pembelajaran. Jenis boneka yang biasanya digunakan adalah boneka tangan yang terbuat dari potongan kain. Tujuan dari penelitian ini adalah untuk mengetahui pengaruh metode bermain peran dengan media boneka tangan terhadap kemampuan berbicara pada siswa TK (4-5 tahun) Budhiyasa Sangsit . Metode: Desain penelitian menggunakan pra-eksperimental dengan rancangan one group pre-post test design. Populasi yang digunakan dalam penelitian ini adalah siswa TK (4-5 tahun) Budhiyasa Sangsit. Besar sampel yang digunakan adalah 30 responden yang telah dipilih dengan menggunakan teknik sampling total sampling. Pengukuran kemampuan berbicara dikumpulkan dengan menggunakan lembar observasi yang berpedoman pada tugas-tugas menurut usia di Denver II. Penelitian ini menggunakan statistik parametrik menggunakan uji Paired Sample Ttest dengan taraf signifikan $\alpha=0,05$. Hasil: Hasil penelitian menunjukkan rata-rata (mean) pre-test adalah 56,00 dan rata-rata (mean) post-test adalah 68,33. Hasil uji statistik parametrik menggunakan uji Paired Sample T-test didapatkan hasil pre dan post $(0,000)<\alpha(0,05)$, yang berarti $\mathrm{H}_{0}$ ditolak dan $\mathrm{H}_{\mathrm{a}}$ diterima. Kesimpulan: Hal ini menunjukkan bahwa terdapat Pengaruh Metode Bermain Peran denagan Media Boneka Tangan terhadap Kemampuan Berbicara pada Siswa TK (4-5 tahun) Budhiyasa Sangsit.
\end{abstract}

Kata Kunci: Media Boneka Tangan, Kemampuan Berbicara, Anak

\begin{abstract}
Introduction: Hand puppets are puppets used as media or tools used in learning activities. The type of doll that is usually used is a hand puppet made of pieces of cloth. The purpose of this study was to determine the effect of the role playing method with hand puppet media on the speaking ability of children aged 4-5 years at Budhiyasa Kindegardeen. Method: The study design used pre-experimental design with one group pre-post test design. The population used in this study were children aged 4-5 years at Budhiyasa Kindegardeen.. The sample size used is 30 respondents who have been selected using the total sampling technique. Measurement of speech ability was collected using an observation sheet guided by assignments according to age in Denver II. This study uses parametric statistics using the Paired Sample T-test with a significant level of $\alpha=0.05$. Results: The results showed the mean (pre-test) was 56.00 and the post-test mean was 68.33. The results of parametric statistical tests using the Paired Sample T-test results obtained pre and post $(0,000)<\alpha(0.05)$, which means that HO is rejected and Ha is accepted. Conclusion: This shows that there is an influence of the method of playing the role of the Denagan Media Hand Puppets on the ability to speak to children aged 4-5 years in Singaraja Telkom ECD.
\end{abstract}

Keywords: Hand Puppet Media, Speaking Ability, Children

\section{PENDAHULUAN}

Pertumbuhan dan perkembangan ialah salah satu aspek penting yang terjadi pada makhluk hidup agar dapat menjaga kelangsungan hidup serta keturunan. Pada dasarnya pertumbuhan (growth) dan perkembangan (development) memiliki arti sama yaitu sama-sama mengalami perubahan, tetapi apabila dibandingkan secara khusus keduanya memiliki perbedaan. (Sri, 2015:4).

http://ejournal.stikesbuleleng.ac.id/index.php/Midwinerslion | 368 
Anak-anak berkembang mulai dari melakukan suatu ekspresi selanjutnya melakukan ekspresi dengan komunikasi. Mereka biasanya sudah mampu mengembangkan pemikiran melalui percakapan yang dapat menarik perhatian orang lain. Mereka juga bisa menggunakan bahasa dengan berbagai macam cara contohnya bertanya, berdialog dan bernyanyi. Saat berusia dua tahun anak akan menunjukan minat untuk 
menyebut nama benda dan terus berkembang sejalan dengan bertambahnya umur mereka sehingga dapat berkomunikasi dengan lingkungan yang lebih luas dan mampu menggunakan bahasa dengan ucapan yang lebih banyak (Mulyasa, 2012:27).

Bahasa adalah suatu alat komunikasi yang dinyatakan berbentuk tulisan, lisan, isyarat atau gerak yang digunakan untuk menyampaikan pikiran dan perasaan. Terdapat empat askep dalam perkembangan bahasa antara lain menyimak, mendengar, menulis dan bicara (Mulyasa, 2012:27).

Bicara yaitu keterampilan mental motorik dengan salah satu bagian dari keterampilan bahasa yang tidak hanya melibatkan koordinasi kumpulan otot mekanisme suara yang berbeda tetapi juga memiliki aspek mental yaitu kemampuan mengaitkan arti bunyi yang dihasilkan. Sebelum anak cukup dapat mengendalikan mekanisme otot saraf untuk menimbulkan bunyi yang jelas, berbeda dan terkendali, ungkapan suara hanya merupakan bunyi artikulasi. Alur perkembangan bicara sama dengan perkembangan motorik dan perkembangan mental dan juga setiap orang akan mengikuti alur yang sama dengan laju perkembangan yang berbeda-beda. Maka dari itu, keterampilan bicara anak dimulai pada usia yang berbeda-beda dengan kualitas bicara anak yang berbeda pula (Mulyasa, 2012:27-28).

Kemampuan bicara anak akan berdampak pada kecerdasan. Kemampuan untuk menguasai keterampilan berbicara tidak tumbuh dengan sendirinya melainkan melalui proses pembelajaran. Salah satu proses pembelajaran yang harus dilatih untuk keterampilan berbicara adalah dengan metode bercerita. Berdasarkan hasil penelitian (Anggreni, Antara, \& Ujianti, 2016) menggunakan metode bercerita dengan boneka jari setelah dilakukan uji coba pada siklus I sehingga pada uji coba ke II mengalami peningkatan kemampuan berbicara yang didapatkan dengan menghitung rata-rata presentase dengan hasil yaitu $89.37 \%$. Peningkatan kemampuan berbicara anak dari siklus I ke siklus II setelah dilakukan metode bercerita terdapat peningkatan sebanyak 20.94\%. Setelah dilakukan metode bercerita maka membuktikan bahwa terjadi peningkatan kemampuan berbicara anak kelompok B. Hasil penelitian ini membuktikan bahwa metode bercerita mampu meningkatkan kemampuan berbicara anak dengan katagori yang tinggi. 
Selain metode bercerita ada banyak proses pembelajaran yang dilakukan untuk menguasai keterampilan

berbicara. Pembelajaran

adalah pencapaian kurikulum yang menuntut aktivitas guru dalam menciptakan dan menumbuhkan kegiatan sesuai dengan rencana yang telah diprogramkan. Seorang guru harus menguasai prinsip-prinsip pembelajaran, pemilihan, dan penggunaan metode, keterampilan menilai hasil belajar, serta memilih dan menggunakan strategi atau pendekatan pembelajaran. (Mulyasa, 2012: 145-147). Pembelajaran berbasis sentra adalah model yang paling mutakhir yang dilaksanakan dilingkungan pendidikan anak usia dini, pada karakteristik utamanya memberikan pijakan (scaffolding) digunakan untuk membangun konsep aturan, ide dan pengetahuan anak serta konsep densitas dan intensitas bermain. Sentra bermain juga dilengkapi dengan seperangkat alat bermain yang fungsinya untuk pijakan lingkungan yang diperlukan untuk mendukung kemajuan perkembangan anak dalam 3 jenis bermain, misalnya bermain sensori motor atau fungsional, bermain peran dan bermain pembangunan (konstruktif, yaitu membangun pemikiran anak) (Mulyasa, 2012:148-150).

Bermain peran atau disebut juga bermain simbolik, main pura-pura, makebelieve, imajinasi. Pada saat bermain peran, anak seolah-olah akan masuk ke dalam dunianya sendiri yang penuh dengan keajaiban dan petualangan sama seperti yang dialami oleh karakter favoritnya di $\mathrm{TV}$, biasanya orang tua diajak ikut masuk dan arut di dalamnya. Adapun manfaat dari bermain peran adalah membangun kepercayaan diri pada anak, mengembangkan kemampuan berbahasa, meningkatkan kreativitas dan akal, membuka kesempatan untuk memecahkan masalah, membangun kemampuan sosial dan empati, memberi anak pandangan positif (Madyawati, 2016: 156-159). Untuk meningkatkan kreatifitas anak diperlukan media pembelajaran yang menarik dan bervariasi. Salah satu media penunjang yang dapat membantu anak adalah dengan media boneka tangan.

Media boneka tangan merupakan boneka yang dijadikan media atau alat bantu yang digunakan dalam kegiatan pembelajaran. Jenis boneka yang biasanya digunakan adalah boneka tangan yang terbuat dari potongan kain. Boneka yang digunakan akan mewakili tokoh cerita yang disampaikan. Tokoh yang diwakili oleh boneka tersebut biasanya merupakan anggota keluarga, misalnya ayah, ibu, anak laki-laki, 
anak perempuan, kakek, dan nenek. Tidak hanya itu, boneka bisa mewakili tokoh satwa dalam sebuah fabel, misalnya kancil, buaya, monyet, dan kura-kura (Madyawati, 2016:184186).

Hal ini sejalan dengan penelitian (Marini et al., 2015) menggunakan metode bermain dengan boneka tangan pada siklus I sebesar $63,31 \%$ dan rata-rata presentase keterampilan berbicara pada anak kelompok B3 semester II di TK Budhi Luhur Sudaji pada siklus II sebesar $80,81 \%$ ini menunjukan adanya peningatan rata-rata pada anak dari siklus I ke siklus II sebesar $17,50 \%$.

Beberapa data menunjukan bahwa angka kejadian anak yang mengalami keterlambatan bicara tergolong cukup tinggi. Menurut penelitian yang dilakukan di Amerika Serikat prevalensi keterlambatan bicara, antara 5\% sampai $8 \%$, dan keterlambatan melaporkan prevalensi antara 2,3\% sampai 19\% (Safitri, 2018).

Berdasarkan studi pendahuluan yang dilakukan oleh peneliti pada bulan Januari 2019 di TK Buhiyasa Sangsit, didapatkan jumlah keseluruhan anak didiknya 55 anak dengan usia 4-5 tahun dan terdapat dua kelas. Berdasarkan hasil wawancara yang peneliti lakukan kepada guru di TK Budhiyasa Sangsit beberapa guru mengatakan bahwa dari 55 anak hanya 15 orang anak yang kemampuan bicaranya cukup dan 30 anak yang bicaranya kurang. Guru TK Budhiyasa Sangsit mengatakan 30 anak belum mampu mengkomunikasikan yang terjadi pada diri sendiri, dilingkungan, mengungkapkan ide dan berbicara dengan berani. Terbukti peneliti mencoba 10 orang anak untuk diajak berbicara, saat diukur menggunakan lembar denver II didapatkan hasil interprestasi bahwa 3 orang anak dikategorikan normal, karena anak mampu mengetahui tiga kata sifat, mengerti lima kata dan mampu menyebutkan empat warna, 6 orang anak yang mengalami caution karena anak gagal pada garis umur yang terletak antara persentil $75 \%$ dan $90 \%$ seperti : anak hanya mampu mengartikan tiga kata dari lima kata, anak hanya mampu mengetahui satu dari tiga kata sifat, dan belum mampu mengungkapkan dua kata yang berlawanan. Sedangkan 1 orang anak yang mengalami delayed karena anak gagal melakukan uji coba yang terletak disebelah kiri garis umur seperti : anak yang harusnya sudah bisa mengerti empat kata depan hanya mampu mengungkapkan satu kata depan, anak yang harusnya sudah bisa menyebutkan empat warna hanya mampu menyebutkan satu warna. 
Mengacu pada latar belakang yang sudah dipaparkan dan melihat fenomena tersebut, peneliti tertarik untuk meneliti Pengaruh Metode Bermain Peran dengan Media Boneka Tangan terhadap Kemampuan Berbicara pada Siswa TK (4-5 tahun) Budhiyasa Sangsit.

\section{METODE PENELITIAN}

Penelitian ini merupakan penelitian eksperimen dimana subyek penelitiannya adalah anak-anak yang berusia 4-5 tahun yang bersekolah di TK Budhiyasa Sangsit, karena dalam penelitian memberikan perlakuan atau intervensi pada objek yang akan diteliti. Desain yang digunakan dalam penelitian ini yaitu One Group PreTest dan Post-Test. Teknik sampling yang digunakan adalah non- probability sampling (total sampling) dengan jumlah sampel 30 orang siswa. Penelitian ini menggunakan alat ukur lembar observasi Denver II dan dilakukan selama 3 minggu di TK Budhiyasa Sangsit.

\section{HASIL PENELITIAN}

Tabel 1 Gambaran Karakteristik Responden Berdasarkan Jenis Kelamin di TK Budhiyasa Sangsit.

\begin{tabular}{ccc}
$\begin{array}{c}\text { Jenis } \\
\text { Kelamin }\end{array}$ & Frekuensi & $\begin{array}{c}\text { Presentase } \\
(\boldsymbol{\%})\end{array}$ \\
\cline { 1 - 1 } Laki-laki & 17 & 56,7 \\
\hline Perempuan & 13 & 43,3 \\
\hline Total & 30 & 100 \\
\hline
\end{tabular}

Berdasarkan tabel 1 didapatkan hasil bahwa sebagian besar responden dengan jenis kelamin laki-laki yaitu 17 orang $(56,7 \%)$.

Tabel 2 Gambaran Karakteristik Responden Berdasarkan Usia di TK Budhiyasa Sangsit.

\begin{tabular}{ccccc}
\hline Variabel & $\begin{array}{c}\text { Usia } \\
\text { Min }\end{array}$ & $\begin{array}{c}\text { Usia } \\
\text { Mak }\end{array}$ & Mean & $\begin{array}{c}\text { Jumlah } \\
(\mathrm{N})\end{array}$ \\
\hline Usia & 4 & 5 & 4,57 & 30 \\
\hline
\end{tabular}

Berdasarkan tabel 2 menunjukkan rata-rata umur responden yaitu 4,57 tahun dengan rentang umur 4-5 tahun. 
Tabel 3 Gambaran Kemampuan Berbicara responden di TK Budhiyasa Sangsit sebelum diberikan Intervensi.

\begin{tabular}{lcc}
\hline $\begin{array}{l}\text { Kemampuan } \\
\text { Berbicara }\end{array}$ & Frekuensi & $\begin{array}{l}\text { Persentase } \\
(\%)\end{array}$ \\
\hline Advanced & 5 & 16,7 \\
Normal & 8 & 26,7 \\
Caution & 16 & 53,3 \\
Delayed & 1 & 3,3 \\
\hline Total & $\mathbf{3 0}$ & $\mathbf{1 0 0}$ \\
\hline
\end{tabular}

Berdasarkan tabel 3 dapat disimpulkan bahwa dari 30 responden sebagian besar masuk dalam kategori Caution dengan jumlah 16 (53,3\%).

Tabel 4 Skor Kemampuan Berbicara responden di TK Budhiyasa Sangsit sebelum diberikan intervensi metode bermain peran.

\begin{tabular}{|c|c|c|c|c|c|}
\hline Data & Mean & $\mathbf{N}$ & $\begin{array}{l}\text { Std. } \\
\text { Deviati } \\
\text { on }\end{array}$ & $\begin{array}{l}\text { Std. } \\
\text { Error } \\
\text { Mean }\end{array}$ & $\begin{array}{l}\text { CI } \\
95 \%\end{array}$ \\
\hline $\begin{array}{l}\text { Pre } \\
\text { Test }\end{array}$ & 56,00 & 30 & 16,103 & 2,940 & $\begin{array}{l}49,99 \\
62,01\end{array}$ \\
\hline
\end{tabular}

Berdasarkan tabel 4 dapat disimpulkan bahwa dari 30 orang jumlah responden yang menjadi subjek penelitian rata-rata (mean) skor kemampuan berbicara sebelum pemberian metode bermain peran dengan media boneka tangan adalah 56,00.

Tabel 5 Gambaran Kemampuan Berbicara responden di TK Budhiyasa Sangsit setelah diberikan Intervensi

\begin{tabular}{lcc}
\hline $\begin{array}{l}\text { Kemampuan } \\
\text { Berbicara }\end{array}$ & Frekuensi & $\begin{array}{l}\text { Persentase } \\
(\%)\end{array}$ \\
\hline Advanced & 9 & 30,0 \\
Normal & 17 & 56,7 \\
Caution & 4 & 13,3 \\
\hline Total & $\mathbf{3 0}$ & $\mathbf{1 0 0}$ \\
\hline
\end{tabular}

Berdasarkan tabel 5 dapat disimpulkan bahwa dari 30 responden sebagian besar masuk dalam kategori Normal dengan jumlah 17 (56,7\%).

Tabel 6 Skor Kemampuan Berbicara Anak Usia 4-5 Tahun di TK Budhiyasa Sangsit setelah diberikan intervensi metode bermain peran

\begin{tabular}{llllll}
\hline Data & Mean & N & $\begin{array}{l}\text { Std. } \\
\text { Devia } \\
\text { tion }\end{array}$ & $\begin{array}{l}\text { Std. } \\
\text { Error } \\
\text { Mean }\end{array}$ & $\begin{array}{l}\text { CI } \\
\mathbf{9 5 \%}\end{array}$ \\
$\begin{array}{l}\text { Pre } \\
\text { Test }\end{array}$ & 68,33 & 30 & 12,341 & 2,253 & $63,73-$ \\
\cline { 1 - 2 } & & & & & $\underline{72,94}$ \\
\hline
\end{tabular}

Berdasarkan tabel 6 dapat disimpulkan bahwa dari 30 orang jumlah responden yang menjadi subjek penelitian rata-rata (mean) skor kemampuan berbicara setelah pemberian metode bermain peran dengan media boneka tangan adalah 68,33.

Tabel 7 Uji normalitas Shapiro-Wilk $(\mathrm{n}=30)$

\begin{tabular}{lcc}
\hline \multicolumn{2}{l}{ Shapiro-Wilk } & \\
\hline & Df & Sig. \\
\hline Pre test & 30 & 0,063 \\
Post test & 30 & 0,073 \\
\hline
\end{tabular}

Berdasarkan tabel 7 menunjukkan bahwa dari 30 responden nilai p-value sebelum intervensi 0,063 dan nilai $p$-value setelah intervensi 0,073 .

Tabel 8 Hasil Uji Pre dan Post Test dengan menggunakan Uji Paired T-test

\begin{tabular}{|c|c|c|}
\hline Variabel & Mean & P.Value \\
\hline $\begin{array}{l}\text { Sebelum } \\
\text { Intervensi }\end{array}$ & 56,00 & 0,000 \\
\hline $\begin{array}{l}\text { Sesudah } \\
\text { Intervensi }\end{array}$ & 68,33 & 0,000 \\
\hline
\end{tabular}

Berdasarkan tabel 8 didapatkan hasil menggunakan uji Paired Sample T-test yang menunjukkan bahwa hasil sig. (2-tailed) atau nilai $\mathrm{p}=0,000$, yang berarti karena nilai $\mathrm{p}$ lebih kecil dari 0,05 $(\mathrm{p}<0,05)$ maka hipotesis nol $\left(\mathrm{H}_{0}\right)$ ditolak. Sehingga dapat disimpulkan bahwa terdapat pengaruh metode bermain peran dengan media boneka tangan terhadap peningkatan kemampuan berbicara pada anak usia 4-5 tahun di TK Budhiyasa Sangsit.

\section{PEMBAHASAN}

Karakteristik responden menunjukkan bahwa dari 30 responden, distribusi frekuensi responden berdasarkan jenis kelamin didapatkan mayoritas laki-laki sebanyak 17 orang $(56,7 \%)$, dan perempuan 13 orang $(43,7 \%)$. Berdasarkan usia menunjukkan bahwa http://ejournal.stikesbuleleng.ac.id/index.php/Midwinerslion | 374 
Jurnal Kesehatan MIDWINERSLION

Vol. 5, No. 2, September 2020

usia tertinggi 5 tahun dan usia terendah 4 tahun, 
dengan rata-rata usia 4,57 tahun. Usia 4-5 tahun merupakan masa peka, masa sensitif dan masa keemasan (golden age) bagi perkembangan anak.

Gambaran Kemampuan Bicara Anak Usia 4-5 Tahun Sebelum Mendapatkan Metode Bermain Peran Dengan Media Boneka tangan.

Hasil penelitian menunjukan bahwa sebelum diberikan metode bermain peran dengan media boneka tangan, frekuensi kemampuan berbicara responden pada anak usia 4-5 tahun di TK Budhiyasa Sangsit, frekuensi kemampuan berbicara tertinggi berada pada kriteria Caution sebanyak 16 orang anak $(53,3 \%)$ dan frekuensi kemampuan berbicara terendah berada pada kriteria Delayed sebanyak 1 orang anak $(3,3 \%)$. Pendapat tersebut sejalan dengan penelitian yang dilakukan oleh (Wijayati, 2016) yang berjudul "Penggunaan Metode Bermain Peran Dalam Mengurangi Perilaku Agresifitas Anak Tk Desa Sewulan Tahun Ajaran 2015/2016" didapatkan hasil persentase perilaku agresif anak dari $83 \%$ sebelum diterapkan metode bermain peran, menjadi $46 \%$ setelah diberikan metode bermain peran.

Gambaran Kemampuan Bicara Anak Usia 4-5 Tahun Setelah Mendapatkan Metode Bermain Peran Dengan Media Boneka Tangan.

Hasil penelitian menunjukan bahwa setelah diberikan metode bermain peran dengan media boneka tangan frekuensi kemampuan berbicara responden pada anak usia 4-5 tahun di TK Budhiyasa Sangsit, frekuensi kemampuan berbicara tertinggi berada pada kriteria normal sebanyak 16 orang anak $(53,3 \%)$ dan frekuensi kemampuan berbicara terendah berada pada kriteria caution sebanyak 4 orang anak $(13,3 \%)$. Rata-rata (mean) skor kemampuan berbicara setelah diberikan metode bermain peran dengan media boneka tangan adalah 68,33, Standar deviation 12,341,

Standar Error Mean 2,253, dan 95\% Confidence Interval For Mean 63,73-72,94.

Pengaruh Metode Bermain Peran dengan Media Boneka Tangan terhadap Peningkatan Kemampuan Berbicara pada Anak Usia 4-5 Tahun di TK Budhiyasa Sangsit

Sebelum menganalisis Pengaruh metode bermain peran dengan media boneka tangan terhadap Peningkatan Kemampuan Berbicara Pada Anak Usia 4-5 Tahun di TK Budhiyasa Sangsit, peneliti melakukan uji normalitas data menggunakan Shapiro-Wilk. Hasil uji normalitas didapatkan bahwa nilai $p$-value sebelum intervensi adalah 0,063 dan nilai $p$-value setelah intervensi adalah 0,073 . Karena $p$ - 
value yang diperoleh $>0,05$ maka data dikatakan berdistribusi normal.

Uji statistik dalam penelitian ini menggunakan uji statistik parametrik dengan uji Paired Sample T-test. Hasil uji statistik menggunakan uji Paired Sample T-test didapatkan bahwa p-value 0,000 $(\mathrm{p}<0,005)$. Hasil ini menandakan bahwa $\mathrm{H}_{0}$ dalam penelitian ini ditolak dan $\mathrm{Ha}$ diterima yang berarti terdapat Pengaruh Metode bermain peran dengan media boneka tangan terhadap Kemampuan Berbicara Anak Usia 4-5 Tahun di TK Budhiyasa Sangsit. Untuk melihat pengaruh metode bermain peran dengan media boneka tangan terhadap kemampuan berbicara anak Usia 4-5 Tahun di TK Budhiyasa Sangsit, dengan cara membandingkan hasil rata-rata skor kemampuan berbicara sebelum dan setelah intervensi metode bermain peran dengan media boneka tangan diberikan.

Hasil rata-rata (mean) kemampuan berbicara sebelum diberikan intervensi metode bermain peran dengan media boneka tangan adalah 56,00 dan setelah diberikan intervensi metode bermain peran dengan media boneka tangan menjadi 68,33 . Penelitian ini membuktikan adanya pengaruh metode bermain peran dengan media boneka tangan terhadap kemampuan berbicara anak usia 4-5 Tahun di PAUD Telkom Singaraja.

\section{KESIMPULAN \& SARAN}

\section{Kesimpulan}

Berdasarkan hasil penelitian yang dilakukan dari 30 responden sebagian besar berjenis kelamin laki-laki yaitu 17 orang $(56,7 \%)$, rata-rata umur responden yaitu 4,57 tahun, untuk kemampuan berbicara sebelum diberikan metode bermain peran dengan media boneka tangan nilai terbesar adalah 16 orang dengan kategori caution, dan setelah pemberian metode bermain peran dengan media boneka tangan nilai terbesar adalah 16 orang dengan kategori normal. Hasil analisis yang dilakukan menggunakan uji paired sample t-test didapatkan nilai $\mathrm{p}$ value $0.000<0.05$ yang berarti ada pengaruh metode metode bermain peran dengan media boneka tangan terhadap peningkatan kemampuan berbicara pada anak usia 4-5 tahun di PAUD Telkom Singaraja.

\section{Saran}

Peneliti menyarankan agar instasi pendidik dapat menjadikan metode bermain 
peran dengan media boneka tangan sebagai salah satu kegiatan yang diberikan saat kegiatan belajar mengajar dilakukan. bagi para pendidik seperti guru agar mampu menghargai setiap keunikan anak, sehingga anak merasa nyaman, tidak takut untuk melakukan kegiatan pembelajaran guna meningkatkan aspek perkembangan anak. Bagi penelitian selanjutnya diharapkan agar mampu mengembangkan metode bermain peran dengan media boneka tangan, untuk menstimulasi kemampuan lain seperti kepercayaan diri, kreativitas, intelegensi, serta kemampuan sosial dan empati anak.

\section{Referensi}

Anggreni, N. M., Antara, P. A., \& Ujianti, P. R. (2016). Implementasi Metode Bercerita Boneka Jari Untuk Meningkatkan Kemampuan Berbicara Kelompok B2 di TK Negeri Bangli. Pendidikan Anak Usia Dini Universitas Pendidikan Ganesha, 4(2), 1-10.

Madyawati, L. (2016). Strategi Pengembangan Bahasa Pada Anak (1st ed.). jakarta: Kencana.

Marini, K., Pudjawan, K., Asril, N. M., Pendidikan, J., Pendidikan, G., Usia, A., ... Tahun, N. (2015). Penerapan Metode Bercerita Berbantuan Media Boneka Tangan Untuk Meningkatkan Keterampilan Berbicara Pada Anak Kelompok B3 Jurusan Teknologi Pendidikan Fakultas Ilmu Pendidikan Universitas Pendidikan Ganesha e-Journal PG PAUD Universitas Pendidikan Ganesha, 3(1).

Mulyasa. (2012). Manajemen PAUD. Bandung: Rosda.

Safitri, Y. (2018). Faktor-Faktor yang Berhubungan dengan Perkembangan Bahasa Balita di UPTD Kesehatan Baserah Tahun 2016. Jurnal Obsesi: Jurnal Pendidikan Anak Usia Dini, 1(2), 148. https://doi.org/10.31004/obsesi.v1i2.35

Sri, Y. (2015). Asuhan Tumbuh Kembang

Neonatus Bayi-Balita Dan Anak PraSekolah. (M. D. Wildani, Ed.). Bandung.

Wijayati, N. (2016). Penggunaan Metode Bermain Peran Dalam Mengurangi Perilaku Agresifitas Anak Tk Desa Sewulan Tahun Ajaran 2015 / 2016. Prosiding Seminar Nasional Pendidikan, 
(November 2015), 45-48. 